\title{
Simulation of sea surface temperature changes in the Middle Pliocene warm period and comparison with reconstructions
}

\author{
YAN Qing ${ }^{1,2^{*}}$, ZHANG ZhongShi $^{3,1^{*}}$, WANG HuiJun ${ }^{1,4}$, JIANG DaBang $^{1,4,5}$ \& \\ ZHENG WeiPeng ${ }^{6}$ \\ ${ }^{1}$ Nansen-Zhu International Research Centre, Institute of Atmospheric Physics, Chinese Academy of Sciences, Beijing 100029, China; \\ ${ }^{2}$ Graduate University of Chinese Academy of Sciences, Beijing 100049, China; \\ ${ }^{3}$ Bjerknes Centre for Climate Research, UniResearch, Bergen N-5007, Norway; \\ ${ }^{4}$ Climate Change Research Center, Chinese Academy of Sciences, Beijing 100029, China; \\ ${ }^{5}$ Key Laboratory of Regional Climate-Environment Research for Temperate East Asia, Chinese Academy of Sciences, Beijing 100029, China; \\ ${ }^{6}$ National Key Laboratory of Numerical Modeling for Atmospheric Sciences and Geophysical Fluid Dynamics, Institute of Atmospheric Physics, \\ Chinese Academy of Sciences, Beijing 100029, China
}

Received November 8, 2010; accepted January 7, 2011

\begin{abstract}
The Middle Pliocene (ca 3.12-2.97 Ma) is a recent warm period in the Earth's history. In many respects, the warmth of the Middle Pliocene is similar to the probable warm situation of the late 21 st century predicted by climate models. Understanding the Middle Pliocene climate is important in predicting the future climate with global warming. Here, we used the latest reconstructions for the Middle Pliocene-Pliocene Research Interpretation and Synoptic Mapping (PRISM) version 3-to simulate the Middle Pliocene climate with a fully coupled model Fast Ocean Atmosphere Model. From comparison of the results of simulations with reconstructions, we considered two important scientific topics of Middle Pliocene climate modeling: extreme warming in the subpolar North Atlantic and a permanent El Niño in the tropical Pacific. Our simulations illustrate that the global annual mean sea surface temperature (SST) in the Middle Pliocene was about $2.3^{\circ} \mathrm{C}$ higher than that in the pre-industrial era. The warming was stronger at mid- and high latitudes than at low latitudes. The simulated SST changes agree with SST reconstructions in PRISM3 data, especially for the North Atlantic, North Pacific and west coast of South America. However, there were still discrepancies between the simulation of the SST and reconstructions for the subpolar North Atlantic and tropical Pacific. In the case of the Atlantic, the weakened meridional overturning circulation in the simulation did not support the reconstruction of the extremely warm condition in the subpolar North Atlantic. In the case of the tropical Pacific, the whole ocean warmed, especially the eastern tropical Pacific, which did not support the permanent El Niño suggested by the reconstruction. From evaluation of the modeling and reconstruction, we suggest that the above discrepancies were due to uncertainties in reconstructions, difficulties in paleoclimate modeling and deficiencies of climate models. The discrepancies should be reduced through consideration of both the modeling and data.
\end{abstract}

Middle Pliocene, sea surface temperature, permanent El Niño, numerical modeling, extreme warming

Citation: Yan Q, Zhang Z S, Wang H J, et al. Simulation of sea surface temperature changes in the Middle Pliocene warm period and comparison with reconstructions. Chinese Sci Bull, 2011, 56: 890-899, doi: 10.1007/s11434-011-4391-5

Paleoclimate modeling is employed to study paleoclimate evolution through numerical simulations using climate models. It is a tool for better understanding the mechanisms behind past time climate changes as well as a method of

*Corresponding authors (email: yanqing@mail.iap.ac.cn; zhongshi.zhang@bjerknes.uib.no) evaluating the capability and effectiveness of climate models. A model that can reasonably simulate the past climate is thought to be more reliable in predicting the future climate. Over the past two decades, many geological studies have presented results on different time scales through reconstruction [1-7]. In terms of modeling, on the other hand, 
some progress has been made in understanding the mechanisms of past climate changes [8-16], but most modeling studies have focused on the Quaternary climate and little attention has been given to warm periods before the Quaternary.

The Middle Pliocene is a recent warm period before the Quaternary in the Earth's history [17]. It spanned from 3.29 to $2.97 \mathrm{Ma}$ according to the geomagnetic polarity timescale of Berggren et al. [18]. Compared with present conditions, the sea surface temperature (SST) at middle to high latitudes was obviously warmer, the extent and thickness of ice sheets and sea ice were less, the sea level was about $25 \mathrm{~m}$ higher and warmth- or moisture-loving vegetation appeared at middle to high latitudes in the Middle Pliocene. The warming in the Middle Pliocene is similar to the warming at the end of this century predicted by climate models of the IPCC AR4 [17]. Although the Middle Pliocene is not a direct analog of future climate change, analyzing the oceanic and cyrospheric equilibrium responses and feedbacks in the case of a warm climate is beneficial in predicting the future climate. Thus, the Middle Pliocene has become a hot topic in international paleoclimate studies. The Pliocene Paleoclimate Modeling Intercomparison Project (PlioMIP, http://geology.er.usgs. gov/eespteam/prism/prism_pliomip.html) was founded in 2009 to systematically study the climate features and mechanisms of the Middle Pliocene using climate models.

Geological reconstructions for the Middle Pliocene were first carried out in the 1990s. The first reconstruction work, Pliocene Research Interpretation and Synoptic Mapping (PRISM0), was completed by Dowsett et al. [19] in 1994, and updated datasets PRISM1 [20] and PRISM2 [21] were published in 1996 and 1999 respectively. The latest PRISM3 data [22] were made available in 2007. The data show five major differences between the Middle Pliocene and present conditions: (1) the volumes of ice sheets in Greenland and Antarctic were 50\% and 33\% less, respectively, (2) the area of sea ice was less, and the Arctic was free of ice in summer, (3) the global mean sea level was about $25 \mathrm{~m}$ higher, (4) the SST was significantly warmer at middle to high latitudes, while there was little change at low latitudes, and (5) the area of evergreen taiga extended further northward by more than $10^{\circ}$, temperate forests and grasslands expanded northward in Russia and eastern North America and replaced boreal conifer forests, deserts were smaller in Africa and Australia and were replaced by tropical savannas and woodlands, and warm-temperate forests appeared in central Europe [23].

PRISM3 reconstruction showed that the most significant SST differences between the Middle Pliocene and the present were in the subpolar North Atlantic and tropical Pacific. In the subpolar North Atlantic, the reconstruction data [24] indicate that the annual mean SST was $5-10^{\circ} \mathrm{C}$ higher. The warming is thought to be related to more northward heat transportation resulting from strengthened Atlantic
Meridional Overturning Circulation (AMOC) in the Middle Pliocene [25]. In the tropical Pacific, there was warming in the eastern tropical Pacific, but slight cooling in the western tropical Pacific in reconstructions [26,27]. The west-to-east SST gradient weakened in the tropical Pacific. It was suggested that an El Niño condition rather than an oscillation between La Niña and El Niño states was a permanent feature of the Middle Pliocene climate. On the contrary, Rickaby et al. [28] pointed out that the tropical Pacific was dominated by a permanent La Niña condition in the Middle Pliocene, because the SST of the western tropical Pacific warm pool remained relatively stable and consistently higher than the SST of the eastern tropical Pacific, and the tropical Pacific thermocline had a much steeper slope. The concept of a "permanent El Niño" is still a topic of debate. However, most of the above studies demonstrated a weakened west-to-east SST gradient in the tropical Pacific in the Middle Pliocene.

The Middle Pliocene climate has been modeled since the release of the first reconstruction dataset for the Middle Pliocene. Using PRISM0, Chandler et al. [29] simulated the Middle Pliocene climate in the Northern Hemisphere. Sloan et al. [30] then used the PRISM1 reconstruction and investigated the global-scale climate in the Middle Pliocene employing the NCAR GENESIS model. Using PRISM2, Haywood et al. [31,32] simulated the Middle Pliocene climate employing the UKMO model and HadAM3 model respectively. Jiang et al. [33] analyzed the climate sensitivity to changes in the SST, terrestrial vegetation, sea ice extent and continental ice sheet using the atmospheric general circulation model (AGCM) of Institute of Atmospheric Physics. However, the above paleoclimate modeling studies were carried out with AGCMs using prescribed SSTs and/or simple slab ocean models, which were incapable of simulating ocean heat transport, ocean currents and thermohaline circulation [34]. Only a few numerical simulations [34-36] with a fully coupled model have been carried out for the Middle Pliocene, which limits analysis of the mechanisms behind the El Niño-Southern Oscillation (ENSO) and AMOC changes in the Middle Pliocene.

Here, we model the Middle Pliocene climate with a fully coupled model FOAM (Fast Ocean Atmosphere Model) according to PlioMIP. The simulations were based on the PRISM3 boundary conditions with a horizontal resolution of $2^{\circ} \times 2^{\circ}$. We analyzed the SST changes, and compared the simulations with reconstructions of the Middle Pliocene.

\section{Model and experimental design}

\subsection{Model}

FOAM is a fully coupled ocean-atmosphere model without flux adjustment [37]. The atmospheric component of FOAM is a fully parallelized version of Community Climate Model 2 (CCM2) of the National Center for Atmospheric Research with upgraded CCM3 physics. The 
resolution of the atmospheric component is $\mathrm{R} 15,4.5^{\circ}$ latitude $\times 7.5^{\circ}$ longitude, with 18 vertical levels. The ocean component is conceptually similar to the Geophysical Fluid Dynamics Laboratory (GFDL) Modular Ocean Model, and has resolution of $1.4^{\circ}$ latitude $\times 2.8^{\circ}$ longitude and 24 vertical levels. A simple thermodynamic sea ice model is incorporated. A detailed description of the model can be found at the FOAM website (http://www.mcs.anl.gov/research/projects/foam).

FOAM reasonably simulates the present climate [37] and captures major features of the observed tropical climatology [38]. The correlation coefficient of the area-weighted pattern between the simulated and observed ENSO was 0.82 . The simulated ENSO variability agreed well with observations, although the simulated ENSO was weaker [39]. In addition, the simulations obtained with FOAM were consistent with the simulation results of other state-of-the-art climate models [40,41]. Furthermore, FOAM has been widely used in paleoclimate studies [42-47].

\subsection{Experimental design}

Following PlioMIP, a control experiment (pre-industrial era, Exp1) and a Middle Pliocene experiment (Exp2) were carried out. Modern topography and bathymetry, interpolated from the ETOPO2v2 $0.03^{\circ} \times 0.03^{\circ}$ dataset [48], were used in Exp1. Changes in the atmospheric $\mathrm{CO}_{2}$ concentration, sea level, topography and land cover were considered in Exp2. Compared with boundary conditions in Exp1, the concentration of atmospheric $\mathrm{CO}_{2}$ was higher in Exp 2 and reached 405 ppmv. In addition, the sea level was $25 \mathrm{~m}$ higher (ocean depth increased by $25 \mathrm{~m}$ at each grid point of the high-resolution ETOPO2v2 data, and was interpolated to the resolution of FOAM). The Middle Pliocene topography was used in Exp2, which was the present topography in Exp1 combined with the anomaly between the Middle Pliocene [49] and the present topography [50] provided by PRISM3. Finally, land cover was taken as the Middle Pliocene situation [23] in Exp2. In the above two experiments, the Central American Seaway (Panama Gateway) remained closed, while the Bering Strait, Madagascar Strait, Drake Passage, Tasman Gateway, Gibraltar Strait and Indonesian Gateway remained open.

In the above two experiments, the ocean started from present conditions. Both experiments were run for 750 years to reach a quasi-equilibrium. We analyzed averages for the last 50 years of simulation.

\section{Model results}

\subsection{Global SST}

The simulations show that the global annual mean SST in the Middle Pliocene was $2.3^{\circ} \mathrm{C}$ higher than the pre-industrial result. The warming at mid-latitudes was stronger than the warming at low latitudes. In the North Atlantic, the annual mean SST increased by $4-7^{\circ} \mathrm{C}$. In the western North Pacific and Indian Ocean, the SST rose on average by $3-5^{\circ} \mathrm{C}$. Annual mean SST showed an increase of about $3-6^{\circ} \mathrm{C}$ in the Southern Ocean between $40^{\circ} \mathrm{S}$ and $50^{\circ} \mathrm{S}$ (Figure $1(\mathrm{a}))$.

The simulated SST in boreal winter and summer also had a similar warming pattern with stronger warming at mid-latitudes. In boreal winter (Figure 1(b)), the global SST rose on average by $2.4^{\circ} \mathrm{C}$. The warming area in the North Atlantic and western North Pacific became smaller and shifted southward in comparison with the changes of annual mean SST. However, the warming in the Indian Ocean and the Southern Ocean between $40^{\circ} \mathrm{S}$ and $50^{\circ} \mathrm{S}$ were much stronger, with maximum warming of $5-6^{\circ} \mathrm{C}$ in the North Indian Ocean. In boreal summer (Figure 1(c)), the global mean SST increased by $2.3^{\circ} \mathrm{C}$. The warming area expanded in the North Atlantic and western North Pacific. The SST rose up to $7^{\circ} \mathrm{C}$ in the North Atlantic. However, the warming in the Southern Ocean between $40^{\circ} \mathrm{S}$ and $50^{\circ} \mathrm{S}$ weakened.

\subsection{Tropical Pacific SST and ENSO}

The warm pool in the west Pacific and the cold tongue in the east Pacific appeared in both the control experiment and the Middle Pliocene experiment. The two experiments showed similar positions for the centers of the warm pool and the cold tongue, and also similar west-to-east SST gradients with higher SSTs in the western tropical Pacific and lower SSTs in the eastern tropical Pacific. However, there was a double Intertropical Convergence Zone (ITCZ) in the simulations with FOAM.

The annual mean SST was higher over the whole tropical Pacific in the Middle Pliocene in comparison with the pre-industrial control run. However, there was stronger warming $\left(2-3^{\circ} \mathrm{C}\right)$ in the eastern tropical Pacific and weaker warming $\left(1-2^{\circ} \mathrm{C}\right)$ in the western tropical Pacific. Both boreal winter and summer had the same warming pattern. In the Middle Pliocene simulation, the annual mean SST simulated at the ODP 847 site $\left(0.2^{\circ} \mathrm{N}, 84.7^{\circ} \mathrm{W}\right)$ was $2.5^{\circ} \mathrm{C}$ higher than that in the pre-industrial control experiment. In addition, the SST was $2.3^{\circ} \mathrm{C}$ higher in boreal winter and $2.7^{\circ} \mathrm{C}$ higher in boreal summer at this site. At the ODP806 site $\left(0.3^{\circ} \mathrm{N}, 159.3^{\circ} \mathrm{E}\right)$, the simulated $\mathrm{SST}$ was on average $1.8^{\circ} \mathrm{C}$ higher for the whole year, $1.6^{\circ} \mathrm{C}$ higher in boreal winter and $2.2^{\circ} \mathrm{C}$ higher in boreal summer. These two sites were used to reconstruct the west-to-east SST gradient changes for the tropical Pacific in the Middle Pliocene $[26,27]$. The above simulations illustrate that the westto-east SST gradient in the tropical Pacific reduced in the Middle Pliocene. The reduction was due to stronger warming in the eastern tropical Pacific and weaker warming in the western tropical Pacific. This reduction in the gradient is different from the reconstruction, which showed that 

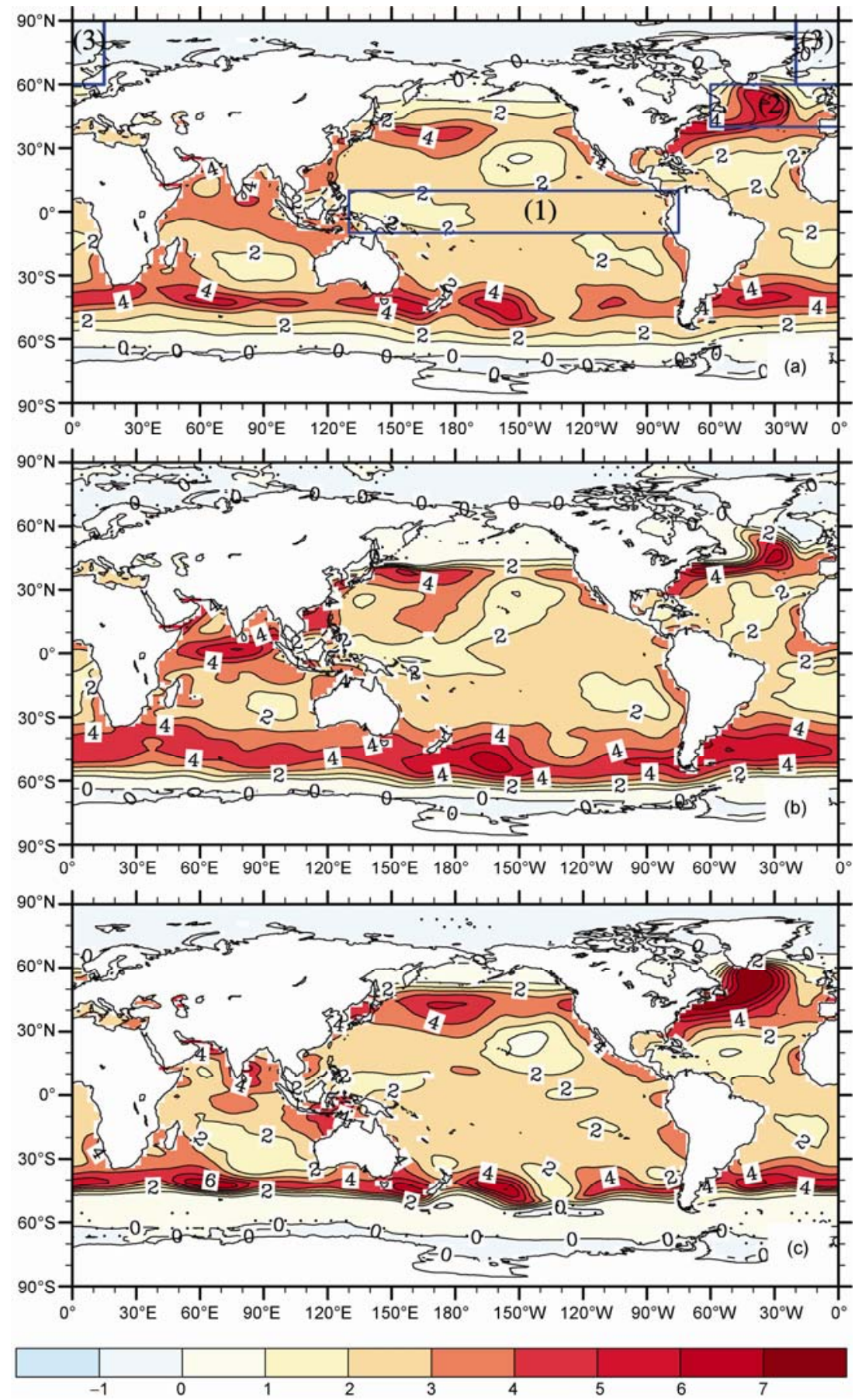

Figure 1 Simulated SST anomalies (unit: ${ }^{\circ} \mathrm{C}$ ) between the pre-industrial run and Middle Pliocene run in terms of annual mean (a), winter (b) and summer (c) values. The dotted areas show the SST changes with a confidence level less than $99 \%$. Rectangles show the regions of the tropical Pacific (rectangle (1) $10^{\circ} \mathrm{S}-10^{\circ} \mathrm{N}, 130^{\circ} \mathrm{E}-75^{\circ} \mathrm{W}$ ), North Atlantic (rectangle (2) $40^{\circ}-60^{\circ} \mathrm{N}, 0^{\circ}-60^{\circ} \mathrm{W}$ ) and subpolar North Atlantic (rectangle $(3) 60^{\circ}-90^{\circ} \mathrm{N}, 0^{\circ}-20^{\circ} \mathrm{W} ; 60^{\circ}-90^{\circ} \mathrm{N}$, $\left.0^{\circ}-15^{\circ} \mathrm{E}\right)$.

the reduction resulted from warming in the eastern tropical Pacific and cooling in the western tropical Pacific.

The ENSO cycle was well simulated in both the control run and the Middle Pliocene experiment. Rotated empirical orthogonal function (REOF) analysis on the SST anomaly (SSTA) in the tropical Pacific shows that the extreme value of the leading mode was located in the middle to eastern tropical Pacific, where the most significant SSTA appeared when El Niño (La Niña) occurred. Thus, the tropical Pacific climate was dominated by an ENSO mode in both experiments. However, the leading mode in the Middle Pliocene run explained more field variance than that in the preindustrial run, which may demonstrate a more significant ENSO cycle in the Middle Pliocene. At the same time, the 
power spectrum of the time series of the leading REOF coefficient showed that the power spectrum peaked at 1.5 years in the Middle Pliocene but at 3 years in the preindustrial run [39]. Thus, El Niño events occurred much more frequently in the Middle Pliocene.

\subsection{North Atlantic/Subpolar North Atlantic SST and AMOC}

In this study, according to the anomalies of SST between the pre-industrial and Middle Pliocene experiments, the whole North Atlantic was divided into two parts: the North Atlantic $\left(40^{\circ}-60^{\circ} \mathrm{N}, 60^{\circ} \mathrm{W}-0^{\circ}\right)$ and subpolar North Atlantic $\left(60^{\circ}-90^{\circ} \mathrm{N}, 0^{\circ}-20^{\circ} \mathrm{W} ; 60^{\circ}-90^{\circ} \mathrm{N}, 0^{\circ}-15^{\circ} \mathrm{E}\right)$. Compared with the results of the pre-industrial experiment, the annual mean SST was $2-6^{\circ} \mathrm{C}$ higher in the North Atlantic in the Middle Pliocene experiment, with stronger warming in boreal winter. In the subpolar North Atlantic, the changes in the annual mean SST were weak, with weak cooling $\left(0^{\circ}-1^{\circ} \mathrm{C}\right)$ in some areas (Figure 1).

In the pre-industrial run, there was strong meridional overturning in the Atlantic. The simulated AMOC intensity was about 24-30 Sv (Figure 2(a)). This agrees with the approximate 27.5-32.5 Sv simulated with the Climate System Model of the National Center for Atmospheric Research [51]. The simulation results were also in the range of observations of approximately $18.7 \pm 5.6 \mathrm{~Sv}$ [52]. Therefore, AMOC was reasonably simulated in the pre-industrial control experiment, although the center of the overturning was deeper and located further south in the experiment. In the Middle Pliocene experiment, the intensity of AMOC was much less (a difference of 8-10 Sv) than that in the pre-industrial control experiment (Figure 2(b)).

\section{Discussion}

\subsection{Comparison of FOAM results with reconstructions and $\mathrm{HadCM} 3$ results}

The PRISM3 reconstruction illustrates that global annual mean SST increased by $1.4^{\circ} \mathrm{C}$ in the Middle Pliocene. In comparison, the simulations employing FOAM showed a warming of $2.3^{\circ} \mathrm{C}$. The spatial pattern of SSTA simulated with FOAM agreed well with the pattern reconstructed from PRISM3, with stronger warming at mid-latitudes. Warming occurred over the North Atlantic, the North Pacific and the west coast of South America (Figure 3(a)). Note that the SSTA in the reconstruction was the difference between the Middle Pliocene and the present [53]. The simulation of SSTA involved comparison between the Middle Pliocene and pre-industrial times. Thus, the warming simulated here was greater than the reconstruction.

Haywood et al. [34] and Lunt et al. [36] carried out Middle Pliocene simulations with the fully coupled model
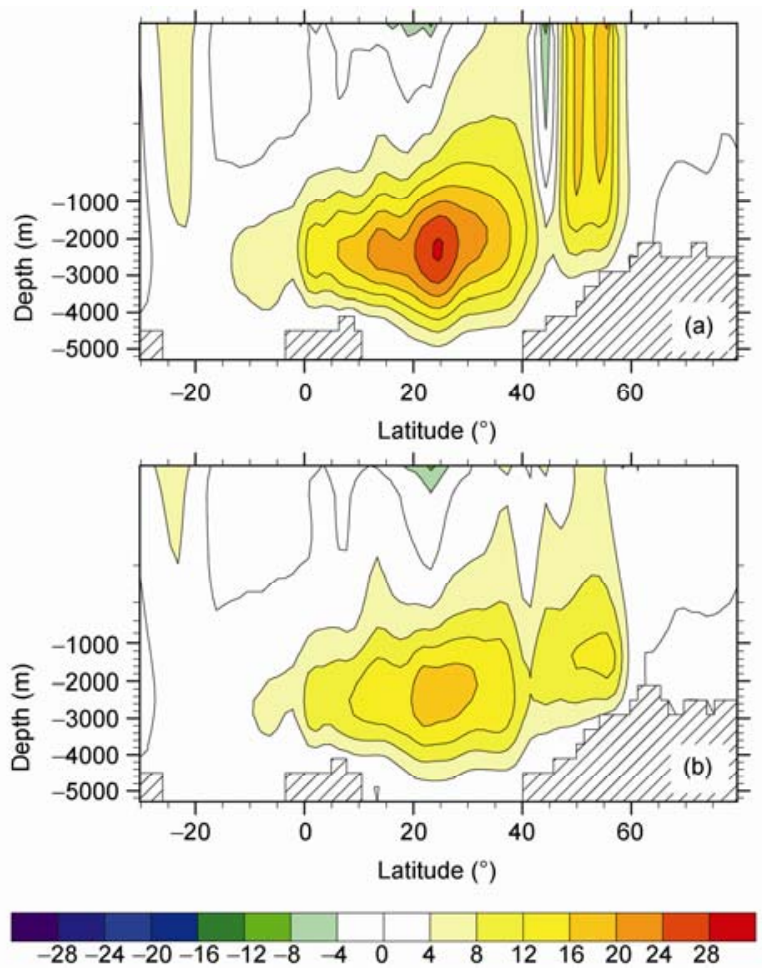

Figure 2 Simulated zonally averaged Atlantic meridional overturning streamfunction for the pre-industrial (a) and Middle Pliocene (b). Unit: Sv $\left(1 \mathrm{~Sv}=10^{6} \mathrm{~m}^{3} \mathrm{~s}^{-1}\right)$

HadCM3 and the PRISM2 reconstruction. PRISM2 is slightly different to PRISM3, because PRISIM3 has been updated to reduce uncertainties in the reconstruction of vegetation and topography $[23,49]$. The small differences only had minor effects on our simulations. The warming of about $2.3^{\circ} \mathrm{C}$ simulated here with FAOM agreed well with the simulation of about $1.8^{\circ} \mathrm{C}$ with HadCM3 [36]. Both simulations showed a weakened AMOC. The intensity of AMOC decreased by $8-10 \mathrm{~Sv}$ in the FOAM simulation and 3-6 Sv in the HadCM3 simulation [34]. The Hadley circulation also weakened, especially in the Pacific, which is consistent with the results of Brierley et al. [54]. In the western North Pacific, the warming magnitude of the SST simulated by FOAM $\left(3-5^{\circ} \mathrm{C}\right)$ in the Middle Pliocene was closer to PRISM3 reconstructions $\left(2-5^{\circ} \mathrm{C}\right)$ than HadCM3 results $\left(5-10^{\circ} \mathrm{C}\right)$. In the center of the North Atlantic $\left(\sim 40^{\circ} \mathrm{N}\right)$, the annual mean SST had a warming pattern of $\sim 3^{\circ} \mathrm{C}$ in both FOAM results and PRISM3 reconstructions, but slight cooling in HadCM3 results.

However, there were large discrepancies in the tropical Pacific and subpolar North Atlantic between the simulations with FOAM/HadCM3 and the PRISM3 reconstructions. Both simulations indicated that the weakened west-to-east SST gradient in the tropical Pacific was due to stronger warming in the eastern tropical Pacific than in the western tropical Pacific (Figure 3(b)). In contrast, the reconstructions showed that the weakened west-to-east SST gradient 

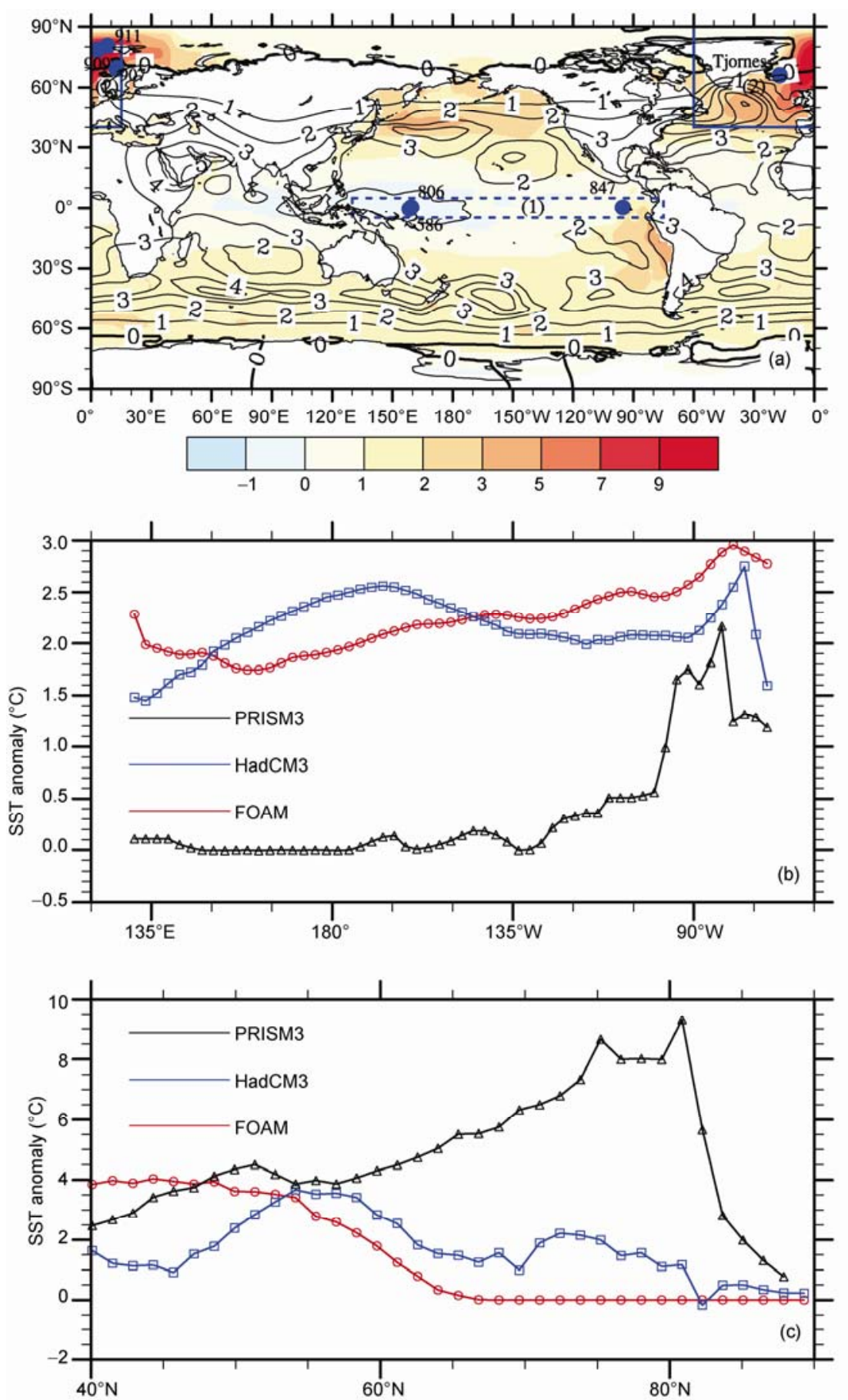

Figure 3 Comparisons of simulations and reconstructions. (a) Reconstructed SST anomalies between the present and the Middle Pliocene (shaded, unit: ${ }^{\circ} \mathrm{C}$ ) and simulated SST anomalies between the pre-industrial run and Middle Pliocene run (contours, unit: ${ }^{\circ} \mathrm{C}$ ). The blue circles represent the geographical locations used to reconstruct the subpolar North Atlantic, western tropical Pacific and eastern tropical Pacific (only one site shown) SST in the Middle Pliocene. (b) The meridional-averaged annual mean SST anomalies $\left({ }^{\circ} \mathrm{C}\right)$ between the pre-industrial era and the Middle Pliocene within $5^{\circ} \mathrm{S}-5^{\circ} \mathrm{N}$. The red line is for FOAM results, blue line for HadCM3 results and black line for PRISM3 reconstructions. (c) Same as (b), but for zonally averaged annual mean SST anomalies $\left({ }^{\circ} \mathrm{C}\right)$ within $0^{\circ}-60^{\circ} \mathrm{W}$ and $0^{\circ}-15^{\circ} \mathrm{E}$.

was due to significant warming in the eastern tropical Pacific and slight cooling in the western tropical Pacific. In the subpolar North Atlantic (Figure 3(c)), the warming magnitude simulated with FOAM was weaker, while stronger warming appeared in the North Atlantic. Simi- larly, the warming magnitude in the subpolar North Atlantic was only $0-2{ }^{\circ} \mathrm{C}$ in HadCM3. The simulated weak warming clearly disagreed with the extreme warming, of up to $9^{\circ} \mathrm{C}$, reconstructed for the subpolar North Atlantic in PRISM3. 


\section{2 "Permanent El Niño"}

Although the definition of a "Permanent El Niño" is still controversial, the concept of a "Permanent El Niño" essentially reflects a weakened west-to-east SST gradient in the tropical Pacific. Uncertainties in the reconstructed SST of the eastern tropical Pacific are relatively small [24,55-57], but uncertainties in the reconstructed SST of the westerntropical Pacific cannot be neglected. Only two sites ODP586 $\left(0.5^{\circ} \mathrm{S}, 158.5^{\circ} \mathrm{E}\right)$ and $\operatorname{ODP} 806\left(0.3^{\circ} \mathrm{N}, 159.4^{\circ} \mathrm{E}\right)-$ were used to reconstruct the SST in the western tropical Pacific in PRISM3. Faunal assemblage-based estimates $[55,58,59]$ show slight cooling $\left(-0.1^{\circ} \mathrm{C}\right)$ in the western tropical Pacific warm pool (ODP806). However, $\mathrm{Mg} / \mathrm{Ca}$ estimates at site ODP806 [27,55] indicate warmer average conditions $\left(+1.1^{\circ} \mathrm{C}\right)$ than the assemblage-based estimates relative to the present. Planktic foraminifer assemblagebased SST estimates for site ODP506 [55] show $0.1^{\circ} \mathrm{C}$ warming relative to the present mean conditions. The nannofossil-based estimates at site ODP1115 $\left(\sim 9^{\circ} \mathrm{S}, 151^{\circ} \mathrm{E}\right)$ [60] also show a relative warming pattern in the western tropical Pacific in the Middle Pliocene.

The simulations with FOAM and HadCM3 both demonstrate warming over the whole tropical Pacific, with larger warming magnitude in the eastern tropical Pacific. The west-to-east SST gradient thus weakened in the simulations. The warming over the whole tropical Pacific was attributed to the increase in the concentration of atmospheric $\mathrm{CO}_{2}$ in the Middle Pliocene experiment. In addition, the tropical Pacific was still dominated by the ENSO mode but with much higher frequencies, which was consistent with the results of HadCM3 [61].

There were also uncertainties in the simulations. The simulated present El Niño was weaker and the simulated cold tongue extended further westward in the control run than in observations. In addition, FOAM simulated a double ITCZ, which was unrealistic and led to a symmetric climatology about the equator [39]. Following PlioMIP, only greenhouse gases, the sea level, topography and land-cover changes were considered in the Middle Pliocene experimental design. Other factors that may have great influence on the Middle Pliocene climate, such as changes in the Greenland-Scotland ridge [62], were neglected in the experiment. On the other hand, representation of the internal physics and parameterization of the model can also introduce uncertainties into the simulations. For example, the role of typhoons in transporting heat from the tropics to the poles [63] was underestimated in climate models. The strong vertical mixing in the upper ocean resulting from typhoons was attributed to the weakened west-to-east SST gradient in the early Pliocene [64].

\subsection{AMOC in the Middle Pliocene}

The annual mean SST derived from PRISM3 data suggests extreme warming in the subpolar North Atlantic, which indicates strengthened AMOC in the Middle Pliocene. The strengthened AMOC could lead to warming in the subpolar North Atlantic, but the warming does not inevitably indicate intensification of AMOC.

$\delta^{13} \mathrm{C}$ records in the Atlantic were used to reconstruct AMOC. $\delta^{18} \mathrm{O}$ and $\delta^{13} \mathrm{C}$ values, reconstructed from benthic foraminifera data for ODP552 $\left(56^{\circ} \mathrm{N}, 23^{\circ} \mathrm{W}\right)$, ODP607 $\left(41^{\circ} \mathrm{N}, 33^{\circ} \mathrm{W}\right)$, ODP407 $\left(47^{\circ} \mathrm{S}, 7^{\circ} \mathrm{E}\right)$ and ODP849 $\left(0^{\circ}, 111^{\circ} \mathrm{W}\right)$ for the interval from $\sim 3.35$ to $2.95 \mathrm{Ma}$, indicate that during warmer (colder) periods with more negative (positive) $\delta^{18} \mathrm{O}$, the $\delta^{13} \mathrm{C}$ gradient among the above four sites was smaller (larger) than that during the Holocene [65]. Ravelo et al. [66] and Hodell et al. [67] pointed out that the $\delta^{13} \mathrm{C}$ gradient between the North and the South Atlantic has greatly increased since 3.0 Ma. The above evidences suggest a stronger AMOC in the Middle Pliocene than at present. However, ambiguity in the interpretation of paleoclimatic records cannot be ignored. If the intensified AMOC was a cause of extreme warming in the subpolar North Atlantic, we ask why there was almost no change in the $\delta^{13} \mathrm{C}$ values from ODP606, ODP 925 and ODP 552 since $3 \mathrm{Ma}$ [66], which would indicate little change in AMOC since the Middle Pliocene. In the South Atlantic, changes in $\delta^{13} \mathrm{C}$ for ODP1088 $\left(41^{\circ} \mathrm{S}, 3^{\circ} \mathrm{W}\right)$ and ODP1090 $\left(42^{\circ} \mathrm{S}, 9^{\circ} \mathrm{W}\right)$ were completely different [67]. If only considering $\delta^{13} \mathrm{C}$ values from ODP982 $\left(57^{\circ} \mathrm{N}, 15^{\circ} \mathrm{W}\right)$, ODP607 $\left(41^{\circ} \mathrm{N}, 33^{\circ} \mathrm{W}\right)$ and ODP1088, there were only small changes in the $\delta^{13} \mathrm{C}$ gradient between the North Atlantic and South Atlantic since 3 Ma [67]. Thus, whether there is another interpretation of these $\delta^{13} \mathrm{C}$ records remains an open question.

The FOAM and HadCM3 simulations indicate that warming occurred in the North Atlantic and AMOC reduced in the Middle Pliocene. The concentration of atmospheric $\mathrm{CO}_{2}(\sim 405 \mathrm{ppmv})$ was higher in the Middle Pliocene experiment than in the pre-industrial experiment, and led to melting of the sea ice and ice sheet at high latitudes. More freshwater entered the North Atlantic, which resulted in reduced salt density and weaker sinking of deep waters, as many coupled models of the IPCC AR4 simulate for a warm climate with increased concentrations of atmospheric $\mathrm{CO}_{2}[68]$.

\subsection{Discrepancies between FOAM results and PRISM3}

There were discrepancies between the present Middle Pliocene modeling and PRISM3 reconstructions, but they were not simply due to the deficiencies of the climate model. Uncertainties in reconstructions and/or interpretation ambiguity of paleoclimatic records were also main reasons for the above discrepancies. Considering recent studies, it is difficult to evaluate whether the reconstruction or simulation is better. In terms of available simulations employing FOAM and HadCM3, it is still too early to analyze the mechanisms behind the extreme warming in the subpolar 
North Atlantic and the permanent El Niño in the Middle Pliocene.

To analyze the mechanisms behind SST changes in the Middle Pliocene, great efforts are needed in terms of improving both the modeling and data. In terms of modeling, sensitivity experiments with consideration of the specialties of the Middle Pliocene should be carried out to reduce uncertainties. Ensemble simulations with several climate models are also needed to reduce uncertainties in comparing modeling results. Finally, other evidence independent of the PRISM3 reconstruction and PlioMIP experiments needs to be considered; for example, East Asian monsoon changes in the Middle Pliocene. The independent evidence will be useful in understanding global and regional climate changes in the Middle Pliocene.

\section{Conclusions}

In summary, we used PRISM3 boundary conditions to simulate the Middle Pliocene climate with a fully coupled model FOAM. Our simulations illustrated that the global annual mean SST in the Middle Pliocene was about $2.3^{\circ} \mathrm{C}$ higher than the pre-industrial value. The warming was stronger at mid- and high latitudes than at low latitudes. There was strong warming in the North Atlantic, North Pacific, Indian Ocean and Southern Ocean between $40^{\circ} \mathrm{S}$ and $50^{\circ} \mathrm{S}$. The simulation also showed that the west-to-east SST gradient decreased in the tropical Pacific and AMOC weakened in the Middle Pliocene. The above results agree well with the simulation employing HadCM3. Furthermore, the SST results for the western North Pacific and the central North Atlantic were better in the simulation using FOAM than that using HadCM3.

The SST changes simulated with FOAM agreed well with the PRISM3 reconstructions. There was strong warming over the North Atlantic, North Pacific and west coast of South America. However, the warming simulated in the subpolar North Atlantic was much weaker than that in the PRISM3 reconstruction. AMOC was weakened, not intensified, in the simulation. In the tropical Pacific, the west-toeast SST gradient decreased in the Middle Pliocene. The decrease in gradient was due to stronger warming in the eastern tropical Pacific and weaker warming in the western tropical Pacific. It is different from the reconstruction, which showed warming in the eastern tropical Pacific and cooling in the western tropical Pacific.

The above model-data discrepancies were due to uncertainties in reconstructions, difficulties in paleoclimate modeling and deficiencies of the climate models. It is clear that efforts are needed in terms of improving both modeling and data to better our understanding of the warm Middle Pliocene climate.
We would like to thank the PRISM workgroup for providing the Middle Pliocene boundary conditions, Dr. Robert Jacob for providing the FOAM model and Dr. Dan Lunt for providing the model results of HadCM3. We also thank the reviewers and editors who helped improve this manuscript. This work was supported by the National Basic Research Program of China(2009CB421406), the Knowledge Innovation Program of the Chinese Academy of Sciences (KZCX2-YW-Q1-02), and the National Natural Science Foundation of China (4090205 and 40975050).

1 An Z S, Huang Y S, Liu W G, et al. Multiple expansions of C4 plant biomass in East Asia since 7 Ma coupled with strengthened monsoon circulation. Geology, 2005, 33: 705-708

2 Ding Z L, Derbyshire E, Yang S L, et al. Stacked 2.6-Ma grain size record from the Chinese loess based on five sections and correlation with the deep-sea $\delta^{18} \mathrm{O}$ record. Paleoceanography, 2002, 17: 1033, doi:10.1029/2001PA000725

3 Guo Z T, Ruddiman W F, Hao Q Z, et al. Onset of Asian desertification by 22 Myr ago inferred from loess deposits in China. Nature, 2002, 416: 159-163

4 Wang Y J, Cheng H, Edwards R L, et al. A high-resolution absolute-dated late Pleistocene monsoon record from Hulu Cave, China. Science, 2001, 294: 2345-2348

5 Fang X M, Zhao Z J, Li J J, et al. Magnetostratigraphy of the late Cenozoic Laojunmiao anticline in the northern Qilian Mountains and its implications for the northern Tibetan Plateau uplift. Sci China Ser D-Earth Sci, 2005, 48: 1040-1051

6 Wu N Q, Rousseau D D, Liu X P. Response of mollusk assemblages from the Luochuan loess section to orbital forcing since the last 250 ka. Chinese Sci Bull, 2000, 45: 1617-1622

7 Zhu M, Ding Z L, Wang X, et al. High-resolution carbon isotope record for the Paleocene-Eocene thermal maximum from the Nanyang Basin, Central China. Chinese Sci Bull, 2010, 55: 3606-3611

8 Jiang D B, Wang H J, Drange H, et al. Last glacial maximum over China: Sensitivities of climate to paleovegetation and Tibetan ice sheet. J Geophys Res, 2003, 108: 4102, doi:10.1029/2002JD002167

9 Liu X D, Yin Z Y. Sensitivity of East Asian monsoon climate to the uplift of the Tibetan Plateau. Palaeogeogr Palaeoclimatol Palaeoecol, 2002, 183: 223-245

10 Wang H J. Role of vegetation and soil in the Holocene megathermal climate over China. J Geophys Res, 1999, 104: 9361-9367

11 Zhang Z S, Wang H J, Guo Z T, et al. What triggers the transition of palaeoenvironmental patterns in China, the Tibetan Plateau uplift or the Paratethys sea retreat? Palaeogeogr Palaeoclimatol Palaeoecol, 2007, 245: 317-331

12 Wang Y, Roulet N T, Frolking S, et al. The importance of Northern Peatlands in global carbon systems during the Holocene. Clim Past Discuss, 2009, 5: 683-693

13 Wang Y, Mysak L A, Roulet N T. Holocene climate and carbon cycle dynamics: Experiments with the "green" McGill paleoclimate model. Glob Biogeochem Cycle, 2005, 19: GB3022, doi:10.1029/2005GB002484

14 Zhou B T, Zhao P. Inverse correlation between ancient winter and summer monsoons in East Asia (in Chinese)? Chinese Sci Bull, 2009, 54: 3760-3767

15 Cheng J, Liu Z Y, He F, et al. Model evidence for climatic impact of thermohaline circulation on China at the century scale. Chinese Sci Bull, 2010, 55: 3215-3221

16 Brovkin V, Kim J, Hofmann M, et al. A lowering effect of reconstructed Holocene changes in sea surface temperatures on the atmospheric $\mathrm{CO}_{2}$ concentration. Glob Biogeochem Cycle, 2008, 22: GB1016, doi:10.1029/2006GB002885

17 Jansen E, Overpeck J, Briffa K R, et al. Palaeoclimate. In: Solomon S, Qin D, Manning M, et al., eds. Climate Change 2007: The Physical Science Basis. Contribution of Working Group I to the Fourth Assessment Report of the Intergovernmental Panel on Climate Change. Cambridge and New York: Cambridge University Press, 2007

18 Berggren W A, Kent D V, Swisher C C, et al. A revised Cenozoic 
geochronology and chronostratigraphy. In: Berggren W A, Kent D V, Aubry M P, et al., eds. Geochronology, Time Scales and Global Stratigraphic Correlation. Soc Sed Geol Spec Pub, 1995, 54: 129-212

19 Dowsett H J, Thompson R, Barron J, et al. Joint investigations of the middle Pliocene climate I: PRISM paleoenvironmental reconstructions. Glob Planet Change, 1994, 9: 169-195

20 Dowsett H J, Barron J A, Poore R Z. Middle Pliocene sea surface temperatures: A global reconstruction. Mar Micropaleontol, 1996, 27: 13-25

21 Dowsett H J, Barron J A, Poore R Z, et al. Middle Pliocene paleoenvironmental reconstruction: PRISM2. US Geol Surv Open File Rep, 1999. 99-535

22 Dowsett $\mathrm{H}$ J. The PRISM palaeoclimate reconstruction and Pliocene sea-surface temperature. In: Williams M, Haywood A M, Gregory J, et al., eds. Deep-time Perspectives on Climate Change: Marrying the Signal from Computer Models and Biological Proxies. Geological Society of London. London: Micropalaeontological Society, Special Publication, 2007. 459-480

23 Salzmann U, Haywood A M, Lunt D J, et al. A new global biome reconstruction and data-model comparison for the middle Pliocene. Glob Ecol Biogeogr, 2008, 17: 432-447

24 Dowsett H J, Robinson M M, Foley K M. Pliocene three-dimensional global ocean temperature reconstruction. Clim Past Discuss, 2009, 5: 1901-1928

25 Dowsett H J, Cronin T M, Poore R Z, et al. Micropaleontological evidence for increased meridional heat transport in the North Atlantic Ocean during the Pliocene. Science, 1992, 258: 1133-1135

26 Fedorov A V, Dekens P S, McCarthy M, et al. The Pliocene paradox (mechanisms for a permanent El Niño). Science, 2006, 312: 1485-1489

27 Wara W M, Ravelo A C, Delaney L M. Permanent El Niño-like conditions during the Pliocene warm period. Science, 2005, 309: 758761

28 Rickaby R E, Halloran P. Cool La Niña during the warmth of the Pliocene? Science, 2005, 307: 1948-1952

29 Chandler M, Rind D, Robert T. Joint investigations of the middle Pliocene climate II: GISS GCM Northern Hemisphere results. Glob Planet Change, 1994, 9: 197-219

30 Sloan L C, Crowley T J, Pollard D. Modeling of middle Pliocene climate with the NCAR GENESIS general circulation model. Mar Micropaleontol, 1996, 27: 51-61

31 Haywood A M, Valdes P J, Sellwood B W, et al. Modelling middle Pliocene warm climates of the USA. Palaeontol Electron, 2001, 4: 121

32 Haywood A M, Valdes P J, Sellwood B W. Global scale palaeoclimate reconstruction of the middle Pliocene climate using the UKMO GCM: initial results. Glob Planet Change, 2000, 25: 239-256

33 Jiang D B, Wang H J, Ding Z L, et al. Modeling the middle Pliocene climate with a global atmospheric general circulation model. J Geophys Res, 2005, 110: D14107, doi:10.1029/2004JD005639

34 Haywood A M, Valdes P J. Modelling Pliocene warmth: Contribution of atmosphere, oceans and cryosphere. Earth Planet Sci Lett, 2004, 218: 363-377

35 Bonham S G, Haywood A M, Lunt D J, et al. El Niño-Southern Oscillation, Pliocene climate and equifinality. Phil Trans R Soc A, 2009, 367: $127-156$

36 Lunt D J, Haywood A M, Schmidt G A, et al. Earth system sensitivity inferred from Pliocene modelling and data. Nature Geoscience, 2010, 3: 60-64

37 Jacob R L. Low frequency variability in a simulated atmosphere ocean system. Dissertation for the Doctoral Degree. Wisconsin: University of Wisconsin-Madison, 1997

38 Liu Z, Otto-Bliesner B, Kutzbach J, et al. Coupled climate simulation of the evolution of global monsoons in the Holocene. J Clim, 2003, 16: 2472-2490

39 Liu Z, Kutzbach J, Wu L. Modeling climate shift of El Niño variability in the Holocene. Geophys Res Lett, 2000, 27: 2265-2268

40 Boville B, Gent P. The NCAR climate system model, version one. J Clim, 1998, 11: 1115-1130
41 Otto-Bliesner B, Brady E. Tropical Pacific variability in the NCAR climate system model. J Clim, 2001, 14: 3587-3607

42 Lee S Y, Poulsen C J. Sea ice control of Plio-Pleistocene tropical Pacific climate evolution. Earth Planet Sci Lett, 2006, 248: 253-262

43 Liu Z, Wang Y, Gallimore R, et al. Simulating the transient evolution and abrupt change of Northern Africa atmosphere-ocean-terrestrial ecosystem in the Holocene. Quat Sci Rev, 2007, 26: 1818-1837

44 Liu Z, Wang Y, Gallimore R, et al. On the cause of abrupt vegetation collapse in North Africa during the Holocene: Climate variability vs. vegetation feedback. Geophys Res Lett, 2006, 33: L22709, doi: 10. 1029/2006GL028062

45 Notaro M, Wang Y, Liu Z, et al. Combined statistical and dynamical assessment of simulated vegetation-rainfall interactions in North Africa during the mid-Holocene. Glob Change Biol, 2008, 14: 347-368

46 Pierrehumbert R T. High levels of atmospheric carbon dioxide necessary for the termination of global glaciation. Nature, 2004, 429: 646-649

47 Wang Y, Notaro M, Liu Z, et al. Detecting vegetation-precipitation feedbacks in mid-Holocene North Africa from two climate models. Clim Past, 2008, 4: 59-67

48 ETOPO2v2 Global Gridded 2-minute Database. National Geophysical Data Center, National Oceanic and Atmospheric Administration, US Dept of Commerce, http://www.ngdc.noaa.gov/mgg/global/etopo2.html, 2006

49 Sohl L E, Chandler M A, Schmunk R B, et al. PRISM3/GISS topographic reconstruction. US Geol Surv Data Series 419, 2009

50 Edwards M. Global Gridded Elevation and Bathymetry. In: Kineman J J, Ohrenschall M A, eds. Global Ecosystems Database, Version 1.0 (on CD-ROM), Documentation Manual, DISC-A: National Geophysical Data Center, Key to Geophysical Records Documentation No. 26 (Incorporated in: Global Change Database, Volume 1), Boulder, CO, National Oceanic and Atmospheric Administration, 1992, A14-1-A14-4

51 Bryan F O. Climate drift in a multicentury integration of the NCAR climate system model. J Clim, 1998, 11: 1455-1471

52 Cunningham S A, Kanzow T, Rayner D, et al. Temporal variability of the Atlantic Meridional Overturning Circulation at $26.5^{\circ} \mathrm{N}$. Science, 2007, 317: 935-938

53 Reynolds R W, Smith T M. A high-resolution global sea surface temperature climatology. J Clim, 1995, 8: 1571-1583

54 Brierley C M, Fedorov A V, Liu Z H, et al. Greatly expanded tropical warm pool and weakened hadley circulation in the early Pliocene. Science, 2009, 323: 1714-1718

55 Dowsett H J, Robinson M M. Mid-Pliocene equatorial Pacific sea surface temperature reconstruction: A multi-proxy perspective. Phil Trans R Soc A, 2009, 367: 109-125

56 Haywood A M, Dekens P, Ravelo A C, et al. Warmer tropics during the mid-Pliocene? Evidence from alkenone paleothermometry and a fully coupled ocean-atmosphere GCM. Geochem Geophys Geosyst, 2005, 6: Q03010, doi:10.1029/2004GC000799

57 Ravelo A C, Dekens P S, McCarthy M. Evidence for El Niño-like conditions during the Pliocene. GSA Today, 2006, 16: 4-11

58 Andersson C. Transfer function vs. modern analog technique for estimating Pliocene sea-surface temperatures based on planktic foraminiferal data, western Equatorial Pacific Ocean. J Foramin Res, 1997, 27: 123-132

59 Dowsett H J. Faunal re-evaluation of mid-Pliocene conditions in the western Equatorial Pacific. Micropaleontology, 2007, 53: 447-456

60 Siesser W. Pliocene paleoclimatology at ODP site 1115, Solomon sea (southwestern Pacific ocean), based on calcareous nannofossils. In: Huchon P, Taylor B, Klaus A, eds. Process Ocean Drill Program, Science Results, 2001, 180: 1-15

61 Haywood A M, Valdes P J, Peck V L. A permanent El Niño-like state during the Pliocene? Paleoceanography, 2007, 22: PA1213, doi:10. 1029/2006PA001323

62 Wright J D, Miller K G. Control of North Atlantic deep water circulation by the Greenland-Scotland Ridge. Paleoceanography, 1996, 11: 157-170

63 Sriver R L, Huber M. Observational evidence for an ocean heat pump 
induced by tropical cyclones. Nature, 2007, 447: 577-580

64 Fedorov A V, Brierley C M, Emanuel K. Tropical cyclones and permanent El Niño in the early Pliocene epoch. Nature, 2010, 463: 1066-1070

65 Raymo M E, Grant B, Horowitz M, et al. Mid-Pliocene warmth: Stronger greenhouse and stronger conveyor. Mar Micropaleontol, 1996, 27: 313-326

66 Ravelo A V, Andreasen D H. Enhanced circulation during a warm period. Geophys Res Lett, 2000, 27: 1001-1004
67 Hodell D A, Venz-Curtis K A. Late Neogene history of deepwater ventilation in the southern ocean. Geochem Geophys Geosyst, 2006, 7: Q09001, doi:10.1029/2005GC001211

68 Meehl G A, Stocker T F, Collins W D, et al. Global Climate Projections. In: Solomon S, Qin D, Manning M, et al., eds. Climate Change 2007: The Physical Science Basis. Contribution of Working Group I to the Fourth Assessment Report of the Intergovernmental Panel on Climate Change. Cambridge and New York: Cambridge University Press, 2007

Open Access This article is distributed under the terms of the Creative Commons Attribution License which permits any use, distribution, and reproduction in any medium, provided the original author(s) and source are credited. 